\title{
Geleneksel Hastane Eczacılı̆̆ımız Konusunda Bir Anket Çalışması
}

\author{
An Inquiry on the Traditional Hospital Pharmacy in Turkey
}

\author{
İsmail ÜSTEL *
}

Her yd, 4 fakülte ve bunların yanısıra devletleştirilmiş yüksek okullar aracılığıyla çok sayıda eczacı yetişmektedir. Bu eczacılardan büyük bir kısmı eczane açmakta veya sorumlu müdür olmakta, ikinci tercih sırasını hastane eczacılığı almaktadır.

Hastane eczacılığı çokdisiplinli bir bilim dalıdır. Farmasötik bilimlerin yanısıra mikrobiyoloji, biyokimya, fizyoloji gibi tıp bilimlerini ve işletme, personel yönetimi, muhasebe, iş idaresi gibi yönetim bilimlerini de içerir. Hastane eczacılığını iki başlık altında incelemek mümkündür: Geleneksel hastane eczacılığıve klinik eczacılık. Geleneksel hastane eczacılığının konuları arasında ilaç satın alınması, satın alınan ilaçların kontrolü, gerektiği biçimde depolanması, stok düzeyinin kontrolü, servislerden istenen ilaç ve majestral bileşiklerin hazırlanma, kontrol ve dağıtımı, gelir-gider hesaplarının kayıda geçirilmesi, narkotiklerin kontrolü, eczane ve tedavi kurulunun kurulması, eczane bülteni ve hastane formüleri hazırlanması sayılabilir. Son yıllarda sağlık hizmetinin bir ekip çalışması olduğunun daha iyi anlaşılması, tıp ve farmasötik bilimlerde meydana gelen değişmeler sonucu eczacılığın felsefesi değişmiş ve klinik eczacılık doğmuştur. Odak noktası "ilaç" değil "hasta" olan bu yeni dalın konulan arasında ilaç bilgi alma merkezinin kurulması, hekimle birlikte vizite çıkılması, hasta hikayesinin alınması, hasta tabelalarının terapötik yönden kontrolü (doz aşımı, geçimsizlik, etkileşme, aksi reaksiyon,

Redaksiyona verildiği tarih: 15 Mart 1977

* Hacettepe Üniversitesi, Eczacılı Fakültesi, Endüstriyel Eczacılı ve Eczacılık İşletmeciliği Bilim Dalı Asistanı ve Mezuniyet Sonrası Eğitim Fakültesi Öğrencisi 
ilacın neden olduğu hastalık, ilaca ait özel sorunlar), hastanedeki sağlık personelinin eğitimi ve çeşitli klinik araştırmalar sayılabilir.

Hastanede uygulanacak klinik eczacilı̆̆ın temeli, geleneksel hastane eczacılı̆̆ıdır. Geleneksel hastane eczacılı̆̆ 1 hizmetlerinin yeterli olmadı̆̆ 1 durumda, klinik eczacılığa geçiş söz konusu olmaz. $\mathrm{Bu}$ araştırmanın amacı, yurdumuzdaki geleneksel hastane eczacılı̆̆ının bugünkü durumunu bilimsel olarak saptamak ve bu konuda gösterilecek çabalara yön vermektir.

\section{YÖNTEM}

Yurdumuzda ilk kez yapılan bu araştırma Türkiye'de bulunan 50 ve daha çok yataklı tedavi kurumlarının tümünü kapsamaktadır. Bu kurumlar: Sağlık ve Sosyal Yardım Bakanlığına bağlı hastaneler, Sosyal Sigortalar Kurumu hastaneleri, Milli Savunma Bakanlığına bağlı hastaneler ve diğer hastanelerdir. Diğer hastaneler grubunda özel hastaneler, dernek hastaneleri, azınlık hastaneleri, diğer bakanlık hastaneleri, iktisadi devlet teşekkülü hastaneleri, belediye hastaneleri ve fakülte hastaneleri vardır. Poliklinik hastasına da ilaç verilmesi söz konusu olduğundan, 50'den az yataklı SSK hastanelerinde bile görevli eczacı bulunmaktadir. Bu nedenle, yatak sayısına bakılmaksızın SSK hastanelerinin tümü araştırma kapsamına alınmıştır.

Konuyla ilgili bilgiler, soru kağıdı gönderme yöntemiyle sağlanmıştır. Kurumlar arası kıyaslamaya olanak vermesi için, bütün kurumlara tek bir tip soru kağıdı gönderilmiştir. Temel bir araştırma niteliğinde olduğundan, sorular sınırlı sayıda ve genel tutulmuştur. Soru kağıdından sağlanmak istenen bilgiler şunlardır:

a) Yataklı tedavi kurumu hakkında genel bilgiler

b) Başeczacı hakkında genel bilgiler

c) Eczanenin çalışma düzeni ile ilgili bilgiler

Soru kağıtlarının uygulanması posta ile yapılmışve tümüne yakın bir kısmının geri gelmesini sağlamak için adresli ve pullu iade zarfı kullanılmıştır. Geri gelmeyenler için, anket uygulaması iki kez tekrarlanmıştır. Gelen soru kağıtları kodlandıktan sonra bulgular tablo biçimine dönüştürülmüş ve istatistik yöntemlerle incelenmiştir. 


\section{BULGULAR*}

$1-$ GENEL

\section{Hastane Eczacilarinın Ankete Katılma Durumu}

Birinci uygulamada \% 66,5 ikinci uygulamada \% 14.6 ve üçüncü uygulamada \% 6.7 olmak üzere toplam \% 87.8 oranında soru kağıdı cevaplandırılmış olarak geri gelmiştir. Değişik grupların ankete katılma durumu tablo l'de gösterilmiştir.

Tablo I. Hastane Eczacilarının Ankete Katılma Durumu

\begin{tabular}{|c|c|c|c|}
\hline & Katılan & Katılmayan & Toplam \\
\hline SSYB & $216 \quad(\% 88.2)$ & $29 \quad(\% 11.8)$ & 245 \\
\hline SSK & $51 \quad(\% 87.9)$ & $7 \quad\left(\begin{array}{ll}\% & 12.1\end{array}\right)$ & 58 \\
\hline MSB & $37 \quad\left(\begin{array}{ll}\% & 90.2\end{array}\right)$ & $4 \quad\left(\begin{array}{ll}\% & 9.8\end{array}\right)$ & 41 \\
\hline Diğer & $39 \quad\left(\begin{array}{ll}\% & 84.8\end{array}\right)$ & $7 \quad\left(\begin{array}{ll}\% & 15.2\end{array}\right)$ & 46 \\
\hline Toplam & $343 \quad\left(\begin{array}{lll}\% & 87 & 8\end{array}\right)$ & $47 \quad\left(\begin{array}{lll}\% & 12 & .2\end{array}\right)$ & 390 \\
\hline
\end{tabular}

* Bu bölümde "Tüm Yataklı Tedavi Kurumları" denildiğinde, araştırmanın kapsamına giren, yeni SSK hastanelerinin tümü ile SSK dışındaki 50 ve daha çok yataklı tedavi kurumlarından söz edilmektedir.

Her grupta görülen oldukça yüksek katılma oranı, böyle bir anketin yurdumuzda ilk kez uygulanmış olmasıyla açıklanabilir.

\section{Hastanelerdeki Yatak Sayısı Dağılımı}

SSYB hastanelerinin \% 50 si 50-100 yataklı küçük hastanelerdir. $\mathrm{Bu}$ oran SSK hastanelerinde \% 30.6, MSB hastanelerinde \% 35.1 ve diğer hastanelerde \% 41 dir. Görüldüğü gibi, SSYB hastalerinin ve diğer hastanelerin yaklaşık yarısının küçük hastane olmasına karşılık, SSK ve MSB hastanelerinin üçte biri bu sınıftadır. SSK hastanelerinin \% 53 ü 100-250 yataklıdır. MSB hastaneleri ise, yatak sayısı dağılımı bakımından yaygın bir görünüme sahiptir. (Tablo II).

Tablodan görüleceği gibi, Türkiye'deki tüm 50 ve daha çok yataklı tedavi kurumlarının \% 44.6 sı 50-100 yataklı küçük hastanelerdir. 
Tablo I I. Hastanelerdeki Yatak Sayısı Dağılımı

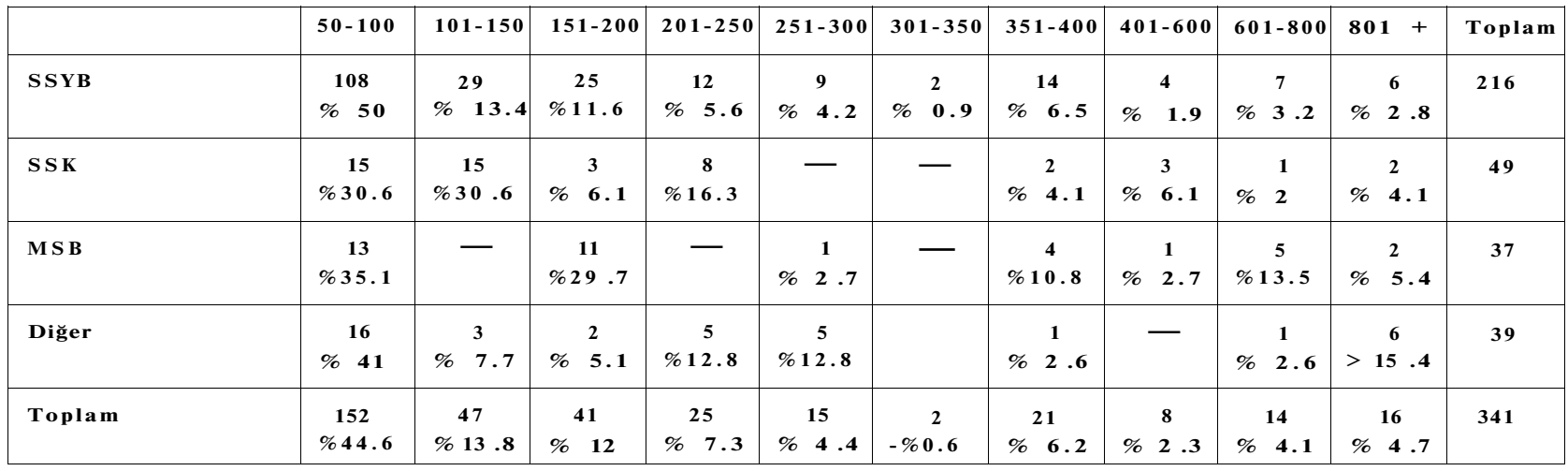




\section{Hastanelerde Eczaci Bulunmasi Durumu}

Çalışmanın yapıldığı dönemde (Mayıs-Haziran 1975) durum şöyledir: SSK ve MSB hastanelerinin tamamında bir veya daha fazla sayıda eczacı bulunmaktadır. SSYB hastanelerinin 40 tanesinde (\% 18.5) ve diğer hastanelerin 9 tanesinde (\% 23.1) eczacı bulunmamaktadir (Tablo III).

Tablo III. Hastanelerde Eczaci bulunması Durumu

\begin{tabular}{|l|c|c|c|}
\hline & var & Yok & Toplam \\
\hline SSYB & $176(\% 81.5)$ & 40 & $21618.5)$ \\
\hline SSK & $51(\% 100)$ & - & 51 \\
\hline MS B & $37(\% 100)$ & - & 37 \\
\hline Diğer & $30(\% 76.9)$ & $9 \%(\% 23.1)$ & 39 \\
\hline Toplam & $294(\% 85.7)$ & $49(\% 14.3)$ & 343 \\
\hline
\end{tabular}

2) HASTANE ECZACILARI

\section{Eczacıların öğrencilikleri Sırasındaki Hastane Stajı Süresi}

SSYB hastanelerinde görevli eczacıların \% 65.3 ü, öğrencilikleri sırasında hiç hastane stajı yapmamışlardır. Bu oran SSK hastanelerinde \% 43.1, diğer hastanelerde ise \% 43.3 tür. MSB hastanelerinde görevli eczacılar, fakültedeki eğitimden sonra Gülhane Askeri Tıp Akademisinde 6 ay - 1 yıl staj yaptıklarından tabloda belirtilmemişlerdir (Tablo IV). Yapılan $x^{2}$ testinde, öğrencilik sırasında staj yapma durumu ve süresi bakımından, her üç grup arasında (SSYB, SSK ve diğer) belirgin farklılık olduğu ortaya çıkmıştır.

SSYB grubunda hiç staj yapmamış olanların, SSK grubunda 3-4 ay staj yapmış olanların, diğer hastaneler grubunda ise 5-6 ay staj yapmış olanların oranı diğer gruplardan yüksektir.

\section{Hastane Eczacilarının Yetersiz Olduğu Konular}

a) Hastane Eczacılarının Kendilerini Yetersiz Bulma Durumu: Her dört grupta da, yüksek oranda eczacı kendisini bir veya birden 
Tablo IV. Eczacıların Öğrencilikleri Sırasındaki Hastane Stajı Süresi

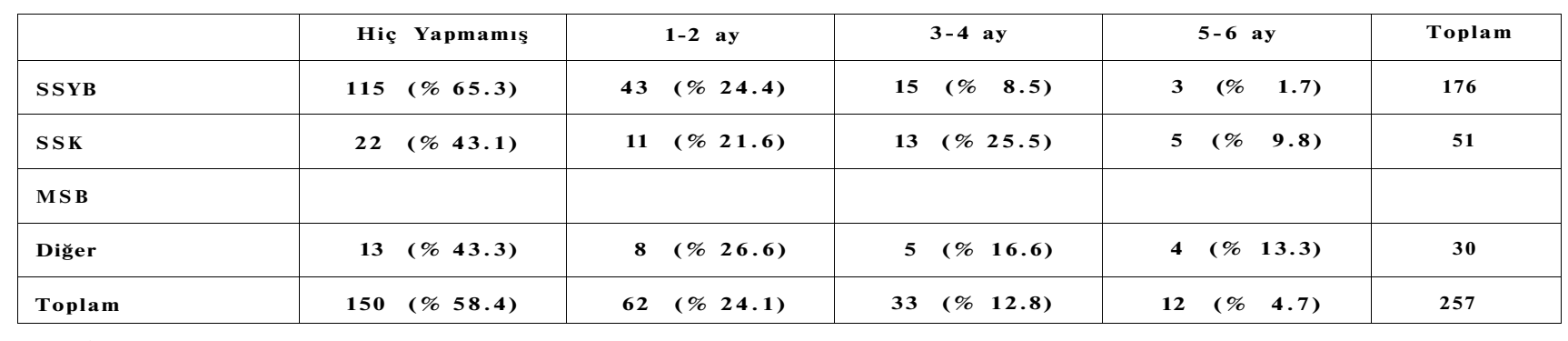

$\mathrm{X}^{2}=25.21 \quad \mathrm{P}<0.05$ 
çok konuda yetersiz bulmaktadır (Tablo V). Yapılan $x^{2}$ testi, eczacıların kendilerini yetersiz bulmaları bakımından, gruplar arasında fark olmadı̆̆ını ortaya koymuştur.

Tablo V. Hastane Eczacilarının Kendilerini Yetersiz Bulma Durumu

\begin{tabular}{|l|c|c|c|}
\hline & Yetersiz Bulanlar & Yeterli Bulanlar & Toplam \\
\hline SSYB & $109(\% 61.9)$ & $67 \quad(\% 38.1)$ & 176 \\
\hline SSK & $36(\% 70.6)$ & $15(\% 29.4)$ & 51 \\
\hline MSB & $26(\% 70.3)$ & $11(\% 29.7)$ & 37 \\
\hline Diğer & $17(\% 56.7)$ & $13(\% 43.3)$ & 30 \\
\hline Toplam & $188(\% 63.9)$ & $106(\% 36.1)$ & 294 \\
\hline
\end{tabular}

$\mathbf{X}^{2}=2.6 \quad \mathbf{P}>0.05$

b) Hastane Eczacilarının Yetersiz Oldukları Konular: Her dört grupta da, eczacıların yetersiz oldukları konuların başında tıbbi ve cerrahi malzeme, tıbbi terminoloji, iş idaresi ve personel yönetimi gelmektedir. MSB hastanelerinde, bunlara ek olarak toksikoloji konusu da önem kazanmaktadır (Tablo VI).

\section{Hastane Eczacılarının Mesleki Gelişmeleri İzleyebilme Durumu}

a) Hastane Eczacıları Mesleki Gelişmeleri izleyebiliyorlar mı?: Her dört grupta da, büyük oranda eczacı, mesleki gelişmeleri izleyebilme olanağından yoksundur (Tablo VII). Yapılan $x^{2}$ testi, eczacıların mesleki gelişmeleri izleyebilme durumu bakımından, gruplar arasında fark bulunmadığını ortaya koymuştur.

b) Hastane Eczacılarının Mesleki Gelişmeleri İzleyememe Nedenleri: SSYB hastanelerindeki eczacıların \% 82.3 ü, mesleki gelişmeleri izleyememe nedeni olarak yayın yetersizliğini (konuyla ilgili yayın olmaması, varsa nasıl sağlanacağının bilinmemesi, iletişim bozukluğu) ileri sürmüşlerdir. Bu oran SSK hastanelerinde \% 51.4, MSB hastanelerinde \% 63.6, diğer hastanelerde ise \% 70.6 dir. SSK hastanelerinde ve diğer hastanelerde görevli eczacılar, ikinci neden olarak zaman ayıramamalarını göstermektedirler (Tablo VIII). 
Tablo VI, Hastane Eczacilarının Yetersiz Oldukları Konular

\begin{tabular}{|c|c|c|c|c|c|c|c|c|c|}
\hline & $\begin{array}{c}\text { İş İda- } \\
\text { resi ve } \\
\text { Personel } \\
\text { Yönetimi }\end{array}$ & $\begin{array}{c}\text { Kayıtla } \\
\text { rin tu- } \\
\text { tulması }\end{array}$ & $\begin{array}{r}\text { Farma- } \\
\text { koloji }\end{array}$ & $\begin{array}{c}\text { Galenik } \\
\text { Farma- } \\
\text { si }\end{array}$ & $\begin{array}{r}\text { Tibbi } \\
\text { ve Cer- } \\
\text { rahiMal } \\
\text { zeme }\end{array}$ & $\begin{array}{r}\text { Toksi- } \\
\text { koloji }\end{array}$ & $\begin{array}{r}\text { Tibbi } \\
\text { Termi- } \\
\text { noloji }\end{array}$ & Diğer & Toplam \\
\hline SSYB & $\begin{array}{c}36 \\
(\% 17.6)\end{array}$ & $\begin{array}{c}21 \\
(\% 10.2)\end{array}$ & $\begin{array}{c}31 \\
(\% 15.1)\end{array}$ & $\begin{array}{cc} & 4 \\
\% & 1.9)\end{array}$ & $\begin{array}{c}50 \\
(\% 24.4)\end{array}$ & 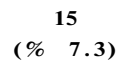 & $\begin{array}{r}43 \\
(\% 21)\end{array}$ & $\begin{array}{c}5 \\
(\% 2.4)\end{array}$ & 205 \\
\hline S S K & $\begin{array}{c}15 \\
(\% 19.7)\end{array}$ & $\begin{array}{c}4 \\
(\% 5.3)\end{array}$ & $\left.\begin{array}{rl} & 7 \\
(\% & 9.2\end{array}\right)$ & $\begin{array}{c}1 \\
(\% \quad 1.3)\end{array}$ & $\begin{array}{c}29 \\
(\% 38.2)\end{array}$ & $\begin{array}{c}6 \\
(\% 7.9)\end{array}$ & $\begin{array}{c}13 \\
(\% 17.1)\end{array}$ & $\begin{array}{c}1 \\
(\% 1.3)\end{array}$ & 76 \\
\hline M S B & $\begin{array}{c}6 \\
(\% 11.5)\end{array}$ & $\begin{array}{c}2 \\
(\% 3.8)\end{array}$ & $\left.\begin{array}{ll} & 2 \\
(\% & 3.8\end{array}\right)$ & $\begin{array}{c}1 \\
(\% 1-9)\end{array}$ & $\begin{array}{c}18 \\
(\% 34.6)\end{array}$ & $\begin{array}{c}7 \\
(\% 13.5)\end{array}$ & $\begin{array}{c}14 \\
(\% 26.9)\end{array}$ & $\left(\begin{array}{ll} & 2 \\
\% & 3.8\end{array}\right)$ & 52 \\
\hline Diğer & $\begin{array}{c}5 \\
(\% 15.1)\end{array}$ & $\begin{array}{c}2 \\
(\% 6.1)\end{array}$ & $\begin{array}{c}4 \\
(\% 12.1)\end{array}$ & - & $\begin{array}{c}8 \\
(\% 24.2)\end{array}$ & $\left.\begin{array}{ll} & 3 \\
(\% & 9.1\end{array}\right)$ & $\begin{array}{c}10 \\
(\% 30.3)\end{array}$ & 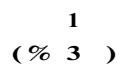 & 33 \\
\hline Toplam & $\begin{array}{c}62 \\
(\% 16.9)\end{array}$ & $\begin{array}{c}29 \\
(\% 7.9)\end{array}$ & $\begin{array}{c}44 \\
(\% 12)\end{array}$ & $\begin{array}{c}\quad 6 \\
(\% 1.6)\end{array}$ & $\begin{array}{c}105 \\
(\% 28.7)\end{array}$ & $\left.\begin{array}{c}31 \\
(\% \quad 8.5\end{array}\right)$ & $\begin{array}{c}80 \\
(\% 21.8)\end{array}$ & $\begin{array}{c}9 \\
(\% 2.5)\end{array}$ & 366 \\
\hline
\end{tabular}


Tablo VII. Hastane Eczacılarının Mesleki Gelişmeleri İzleyebilme Durumu

\begin{tabular}{|c|c|c|c|}
\hline & İzleyebilenler & İzleyemeyenler & Toplam \\
\hline SSYB & $48 \quad\left(\begin{array}{ll}\% & 27.9\end{array}\right)$ & $124\left\{\begin{array}{lll}\% & 72.1)\end{array}\right.$ & 172 \\
\hline S S K & $15(\% \quad 30 \quad)$ & $35 \quad(\% 70 \quad)$ & 50 \\
\hline MSB & $14 \quad(\%$ 38.9) & $(\% 61.1)$ & 36 \\
\hline Diğer & $11 \quad\left(\begin{array}{ll}\% & 39.3\end{array}\right)$ & $17 \quad(\% 60.7)$ & 28 \\
\hline Toplam & $88 \quad\left(\begin{array}{ll}\% & 30.8\end{array}\right)$ & $198 \quad(\% 69.2)$ & 286 \\
\hline
\end{tabular}

$\mathrm{X}^{2}=2.74 \quad \mathrm{P}>0.03$

3) HASTANE ECZANELERİ

\section{Hastaneye Alınacak İlaçların Listesini Hazırlayan Birim}

Yapılan $\mathrm{x}^{2}$ testi, hastaneye alınacak ilaçların listesinin hazırlanması bakımından, her dört grubun da birbirinden farklı olduğunu ortaya koymuştur. SSYB hastanelerinde en çok izlenen yol, listenin başhekim ve başeczacı tarafından hazırlanmasıdır (\% 33.5) Bu oran SSK hastanelerinde \% 27.5, MSB hastanelerinde \% 13.5 ve diğer hastanelerde \% 23.3 tür. Listenin yalnızca başhekim tarafından hazırlanmasına SSK hastanelerinde ve diğer hastanelerde hiç rastlanmamasına, MSB hastanelerinde ise \% 2.7 gibi düşük bir oranda rastlanmasına karşılık, SSYB hastanelerin \% 13.1 inde bu yol izlenmektedir. Listenin yalnızca başeczacı tarafından hazırlanmasına en az SSYB hastanelerinde rastlanmaktadır (\% 26.1) (Tablo IX).

\section{Hastaneye Alınan İlaçların Kontrol Durumu}

a) Hastaneye Alınan İlaçlar Kontrol Ediliyor mu? : Tüm yataklı tedavi kurumlarının \% 79.6 sında, hastaneye alınan ilaçlar kontrol edilmektedir. Kontrol oranı bakımından başta \% 83.3 ile diğer hastaneler gelmekte, onu \% 83 ile SSYB hastaneleri, \% 74.5 ile S S K hastaneleri ve \% 67.6 ile MS B hastaneleri izlemektedir (Tablo $\mathrm{X})$. Yapılan $\mathrm{x}^{2}$ testinde, hastaneye alınan ilaçların kontrolü bakımından, gruplar arasında fark olmadığı anlaşılmıştır. 
Tablo VIII. Hastane Eczacılarının Mesleki Gelişmeleri izleyememe Nedenleri

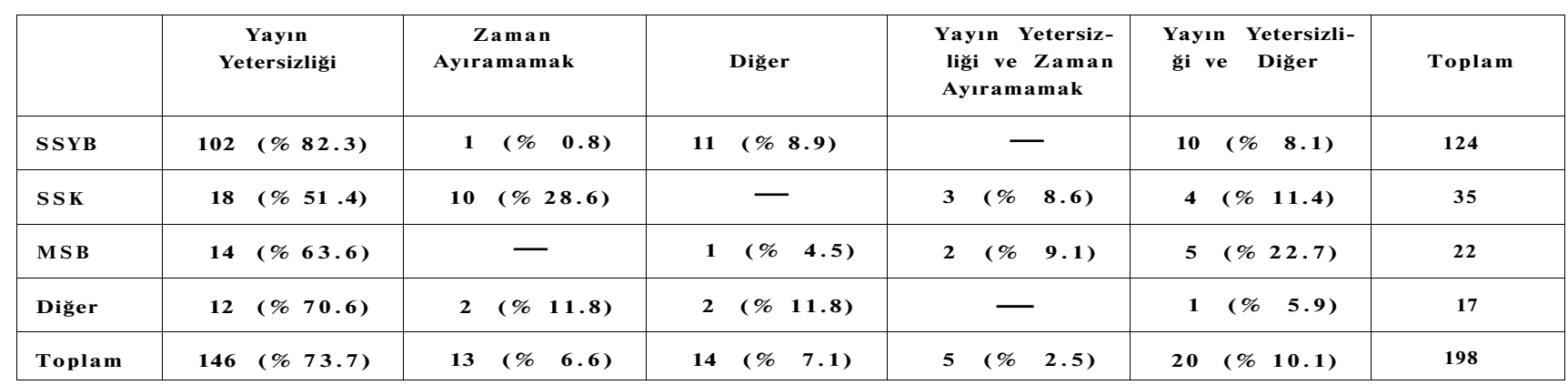


Tablo IX. Hastaneye Alınacak İlaçların Listesini Hazırlayan Birim

\begin{tabular}{|c|c|c|c|c|c|c|c|}
\hline & 1 & 2 & 3 & 4 & 5 & 6 & Toplam \\
\hline SSYB & $23(\% 13.1)$ & $46(\% 26.1)$ & $59(\% 33.5)$ & $40(\% 22.7)$ & $1(\%$ o.6) & $7\left(\begin{array}{ll}\% & 4\end{array}\right.$ & 176 \\
\hline S S K & - & $22(\% 43.1)$ & $14(\% 27.5)$ & $15(\% 29.4)$ & - & - & 51 \\
\hline MSB & $1\left(\begin{array}{lll}\% & 2.7\end{array}\right)$ & $20(\% 54.1)$ & $5 \quad(\% 13.5)$ & $5 \quad(\% 13.5)$ & 一 & $6\left(\begin{array}{ll}\% & 16.2\end{array}\right)$ & 37 \\
\hline Diğer & - & $16(\% 53.3)$ & $7 \quad(\% 23.3)$ & $6(\% 20)$ & $1\left(\begin{array}{ll}\% & 3.3\end{array}\right)$ & - & 30 \\
\hline Toplam & $24\left(\begin{array}{lll}\% & 8.2\end{array}\right)$ & $104(\% 35.4)$ & $85 \quad(\% 28.9)$ & $66(\% 22.4)$ & $2\left(\begin{array}{ll}\% & 0.7\end{array}\right)$ & $13(\% 4.4)$ & 294 \\
\hline
\end{tabular}

$\mathbf{X}^{2}=51.71$

$\mathbf{P}<0.05$

(1: Başhekim; 2: Başeczacı; 3: Başhekim ve başeczacı; 4: Başhekim, başeczacı ve belirli sayıda hekim; 5: Başhekim, başeczacı, başhemşire ve belirli sayıda hekim; 6: Diğer.) 
Tablo X. Hastaneye Alınan ilaçların Kontrol Durumu

\begin{tabular}{|l|c|c|c|}
\hline & Kontrol Ediliyor & Kontrol Edilmiyor & Toplam \\
\hline SSYB & $146(\% 83)$ & $30(\% 17)$ & 176 \\
\hline SSK & $38(\% 74.5)$ & $13(\% 25.5)$ & 51 \\
\hline MSB & $25(\% 67.6)$ & $12(\% 32.4)$ & 37 \\
\hline Diğer & $25(\% 83.3)$ & $5(\% 16.7)$ & 30 \\
\hline Toplam & $234(\% 79.6)$ & $60 \quad(\% 20.4)$ & 294 \\
\hline$X^{2}=5.50$ & $P>0.05$
\end{tabular}

b) Hastaneye Alınan İlaçlarda Yapılan Kontroller: Her dört grupta da sayısal kontrol, kırık ve bozulmuş olanların saptanması, süreli ilaçlarda son kullanma tarihine bakılması gibi fiziksel kontroller önde gelmektedir. Kimyasal veya özel kontroller (örneğin mikrobiyolojik) bütün gruplarda oldukça düşük oranda yapılabilmektedir. Tüm yataklı tedavi kurumlarında yapılan kontrollerin ancak \% 33.4 ü bu tiptendir (tek başına veya diğer kontrollerle birlikte) (Tablo XI).

\section{Hastane Eczanesinde Hazırlanan Farmasötik Şekilleri}

a) Hastane Eczanesinde Farmasötik Şekil Hazırlanması Durumu: Yapılan $\mathrm{x}^{2}$ testi, eczanede farmasötik şekil hazırlanması bakımindan SSYB ve SSK hastaneleri grubu ile MSB ve diğer hasteneler grubunun birbirinden farklı olduğunu ortaya koymuştur. SSYB hastaneleri ile SSK hastaneleri arasında fark yoktur; farmasötik şekil hazırlanması oranı SSYB hastanelerinde \% 64.2, SSK hastanelerinde ise \% 74.5 tir. MSB hastaneleri ile diğer hastaneler arasında da fark yoktur; farmasötik şekil hazırlanması oranı MSB hastanelerinde \% 97.3, diğer hastanelerde ise\%86.7 dir (Tablo XI I). Görüldüğü gibi, ilk gruptaki (SSYB ve SSK) oran, ikinci grubun (MSB ve diğer) oranına göre daha düşüktür.

b) Hastane Eczanesinde Hazırlanan Farmasötik Şekiller: Her dört grupta da, eczanede hazırlanan farmasötik şekillerin başında pomat, paket ve kaşe gelmektedir. Bunları süspansiyon, emülsiyon ve pilül izlemektedir. Diğger gruplardan farklı olarak, MSB hastane- 
Tablo XI. Hastaneye Alınan Haçlarda Yapılan Kontroller

\begin{tabular}{|c|c|c|c|c|c|c|c|c|c|c|c|c|c|c|c|c|}
\hline & 1 & 2 & $1-2$ & 3 & $1-3$ & $2-3$ & $1-2-3$ & 4 & $1-4$ & $2-4$ & 1-2-4 & $3-4$ & 1-3-4 & $2-3-$ & $\begin{array}{c}1-2-3 \\
-4\end{array}$ & $\begin{array}{l}\text { Top- } \\
\text { lam }\end{array}$ \\
\hline SSYB & $\begin{array}{c}13 \\
\% 8\end{array}$ & $\begin{array}{c}3 \\
\% 2.1\end{array}$ & $\begin{array}{c}9 \\
\% 6.2\end{array}$ & - & $\begin{array}{r}16 \\
\% n\end{array}$ & $\begin{array}{c}5 \\
\% 3.4\end{array}$ & $\left|\begin{array}{c}48 \\
\% 32.9\end{array}\right|$ & $\begin{array}{c}2 \\
\% 1.4\end{array}$ & $\begin{array}{c}11 \\
\% 7.5\end{array}$ & $\begin{array}{c}2 \\
\% 1.4\end{array}$ & $\begin{array}{c}1 \\
\% 0.7\end{array}$ & $\begin{array}{c}5 \\
\% 3.4\end{array}$ & $\begin{array}{c}11 \\
\% 7.5\end{array}$ & $\begin{array}{c}1 \\
\% 0.7\end{array}$ & $\begin{array}{c}19 \\
\% 13\end{array}$ & 146 \\
\hline S S K & $\mid \begin{array}{c}5 \\
\% 13.2\end{array}$ & $\begin{array}{c}1 \\
\% 2.6\end{array}$ & $\begin{array}{c}6 \\
\% 15.8\end{array}$ & $\begin{array}{c}1 \\
\% 2.6\end{array}$ & $\begin{array}{c}4 \\
\% 10.5\end{array}$ & $\begin{array}{c}1 \\
\% 2 \\
2.6\end{array}$ & $\begin{array}{c}13 \\
\% 34.2\end{array}$ & $\begin{array}{c}1 \\
\% 2\end{array}$ & $\begin{array}{c}1 \\
\% 2.6\end{array}$ & - & - & $\begin{array}{c}1 \\
\% 2.6\end{array}$ & - & $\begin{array}{c}3 \\
\% 7.9\end{array}$ & $\begin{array}{c}1 \\
\% 2.6\end{array}$ & 38 \\
\hline MS B & - & $\begin{array}{r}1 \\
\% 4\end{array}$ & $\begin{array}{r}1 \\
\% 4\end{array}$ & $\begin{array}{l}1 \\
\% 4\end{array}$ & $\begin{array}{c}3 \\
\% 12\end{array}$ & $\begin{array}{r}1 \\
\% 4\end{array}$ & $\begin{array}{c}6 \\
\% 24\end{array}$ & $\begin{array}{c}3 \\
\% \\
\quad 12\end{array}$ & $\begin{array}{c}4 \\
\% 16\end{array}$ & $\begin{array}{r}1 \\
\% 4\end{array}$ & - & $\begin{array}{c}3 \\
\% 12\end{array}$ & - & - & $\% 4^{1}$ & 25 \\
\hline Diğer & $\begin{array}{r}1 \\
\% 4\end{array}$ & - & $\begin{array}{c}3 \\
\% 12\end{array}$ & $\begin{array}{r}1 \\
\% 4^{1}\end{array}$ & $\begin{array}{r}1 \\
\% 4\end{array}$ & $\begin{array}{r}1 \\
\% 4\end{array}$ & $\begin{array}{c}11 \\
\% 44\end{array}$ & $\begin{array}{r}1 \\
\% 4\end{array}$ & $\begin{array}{r}2 \\
\% 8\end{array}$ & $s-$ & $\begin{array}{r}1 \\
\% 4\end{array}$ & - & $\begin{array}{r}2 \\
\% 8\end{array}$ & - & $\begin{array}{r}1 \\
\% 4\end{array}$ & 25 \\
\hline Toplam & $\begin{array}{c}19 \\
\% 8.1\end{array}$ & $\begin{array}{c}5 \\
\% 2.1\end{array}$ & $\begin{array}{c}19 \\
\% 8.1\end{array}$ & $\begin{array}{c}3 \\
\% 1.3\end{array}$ & $\begin{array}{c}24 \\
\% 10.3\end{array}$ & $\begin{array}{c}8 \\
\% 3.4\end{array}$ & $\left|\begin{array}{c}78 \\
\% 33 . .3\end{array}\right|$ & $\begin{array}{r}7 \\
\% 3\end{array}$ & $\begin{array}{c}18 \\
\% 7.7\end{array}$ & $\begin{array}{c}3 \\
\% 1.3\end{array}$ & $\begin{array}{c}2 \\
\% 0.9\end{array}$ & $\begin{array}{c}9 \\
\% 3.8\end{array}$ & $\begin{array}{c}13 \\
\% 5.6\end{array}$ & $\begin{array}{c}4 \\
\% 1.7\end{array}$ & $\begin{array}{c}22 \\
\% 9.4\end{array}$ & 234 \\
\hline
\end{tabular}

(1: Sayısal kontrol; 2: Kırık ve bozukların saptanması; 3: Son kullanma tarihinin kontrolü 4: Diğer kontroller) 
İsmail Ü S T E L

Tablo XII. Hastane Eczanesinde Farmasötik Şekil Hazırlanması

Durumu

\begin{tabular}{|c|c|c|c|c|c|}
\hline \multirow[b]{2}{*}{ S SYB } & \multicolumn{2}{|c|}{ Hazırlaniyor } & \multicolumn{2}{|c|}{ Hazirlanmiyor } & \multirow{2}{*}{$\begin{array}{c}\text { Toplam } \\
176\end{array}$} \\
\hline & 113 & $(\% 64.2)$ & 63 & $(\% 35.8)$ & \\
\hline S S K & 38 & $(\% 74.5)$ & 13 & $(\% 25.5)$ & 51 \\
\hline MS B & 36 & $\left(\begin{array}{lll}\% & 97.3\end{array}\right)$ & & $\left(\begin{array}{ll}\% & 2.7\end{array}\right)$ & 37 \\
\hline Diğer & 26 & $(\% 86.7)$ & 4 & $\left(\begin{array}{lll}\% & 1 & 3 \\
-3\end{array}\right)$ & 30 \\
\hline Toplam & 213 & $(\% 72.4)$ & 81 & $\left(\begin{array}{lll}\% & 27.6\end{array}\right)$ & 294 \\
\hline
\end{tabular}

$X^{2}=20.64 \quad P<0.05$

lerinde hazırlanan farmasötik şekiller arasında supozituvar da dikkati çekmektedir. (Tablo XIII)

\section{Serviste Yatan Hastalar İçin Eczaneden İlaç İstenmesinde Kullanılan Yöntem}

a) Narkotikler: Yapılan $\mathrm{x}^{2}$ testi, eczaneden narkotik istenmesi bakımından, SSYB ve MSB hastaneleri grubu ile SSK ve diğer hastaneler grubu arasında fark olduğunu ortaya koymuştur. SSYB hastaneleri ile MSB hastaneleri arasında fark yoktur. Her ikisinde de, eczaneden narkotik istenmesinde en sık kullanılan yöntem, narkotik ilacın hasta tabelası ile (normal vizit ve / veya hekim imzası ile kontrvizit) istenmesidir. (\% 84.4 ve $\% 67.5$ ). Narkotiğin uyuşturucu reçete ile istenmesi yöntemi (yalnız başına veya diğer yöntemlerle beraber) bu hastanelerde düşük oranda kullanılmaktadır. ( $\% 10.5$ ve $\% 10.8$ ). SSK hastaneleri ile diğer hastaneler arasında da fark yoktur. Her ikisinde de, eczanden narkotik istenmesinde en sik kullanılan yöntem, narkotik ilacın uyuşuturucu reçete ile istenmesidir. (\% 78.5 ve \% 68.8) (yalnız başına veya diğer yöntemlerle beraber). Narkotiğin hasta tabelası ile (normal vizit ve / veya hekim imzası ile kontrvizit) istenmesi, bu hastanelerde az kullanılan bir yöntemdir. (\% 15.7 ve \% 24.1) (Talo XIV).

b) Diğer ilaçlar: Tüm yataklı tedavi kurumlarında, eczaneden ilâç istenmesinde kullanılan yöntemlerin başında (\% 52.2) hasta tabelası ile isteme gelmektedir. Bunu \% 27.8 ile, hasta tabelesına göre hemşire tarafından hazırlanmış ilaç listesi ile isteme ve \% 14.8 ile, 
Tablo XI I I. Hastane Eczanesinde Hazırlanan Farmasötik Şekiller

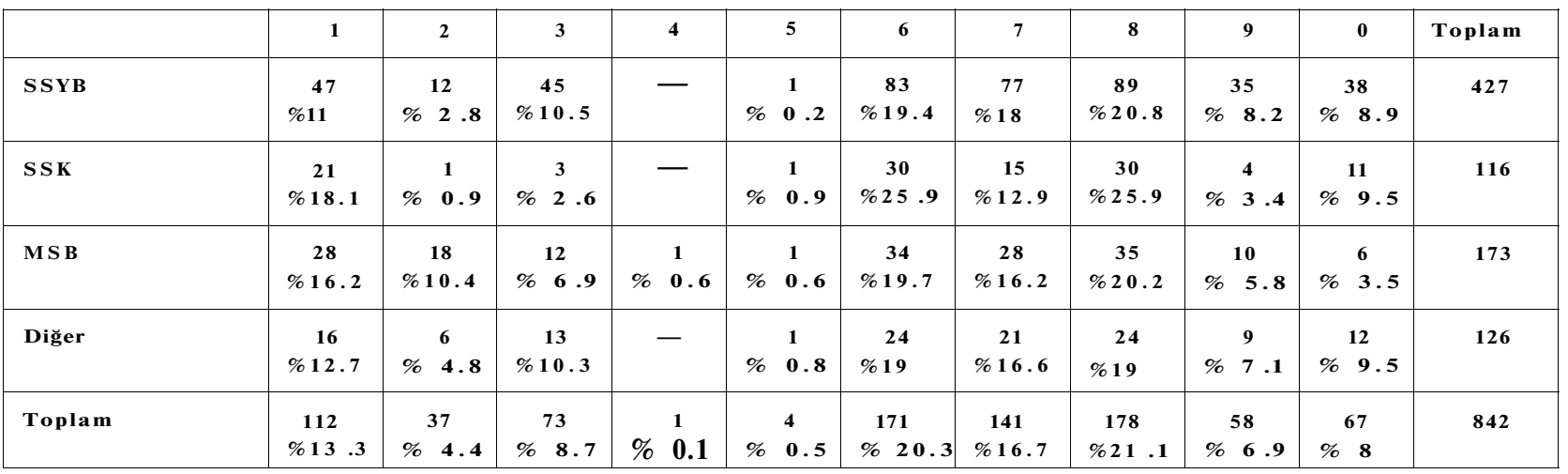

(1: Suspansiyon-Emülsiyon; 2: Supozituvar; 3: Pilül; 4: Tablet; 5: Kapsül; 6: Paket; 7: Kaşe; 8: Pomat; 9: Geniş hacimli parenteral mayi; 0: Diğer) 
Tablo XIV. Eczaneden Narkotik İstenmesinde Kullanılan Yöntem

\begin{tabular}{|c|c|c|c|c|c|c|c|c|c|c|c|c|c|c|c|}
\hline & 1 & 2 & $1-2$ & 3 & & -3 & $2-$ & -3 & 4 & $1-4$ & $2-4$ & $3-4$ & 5 & $2-5$ & $\begin{array}{l}\text { Top- } \\
\text { lam }\end{array}$ \\
\hline SSYB & $\begin{array}{c}60 \\
\% 34.7\end{array}$ & $\begin{array}{c}63 \\
\% 36.4\end{array}$ & $\begin{array}{c}23 \\
\% 133\end{array}$ & $\begin{array}{l} \\
\% 3 \\
\% 3.5\end{array}$ & - & - & $\%$ & $\begin{array}{l}1 \\
0.6\end{array}$ & $\begin{array}{c}10 \\
\% 5.8\end{array}$ & $\begin{array}{c}1 \\
\% \quad 0.6\end{array}$ & - & - & $\begin{array}{c} \\
\quad 8 \\
\% 4.6\end{array}$ & $\begin{array}{c}1 \\
\% 0.6\end{array}$ & 173 \\
\hline S S K & $\begin{array}{ll} & 5 \\
\% & 9.8\end{array}$ & $\begin{array}{ll} & 2 \\
\% & 3.9\end{array}$ & $\begin{array}{ll} & 1 \\
\% & 2\end{array}$ & $\begin{array}{c}10 \\
\% 19.6\end{array}$ & & $\begin{array}{l}3 \\
5.9\end{array}$ & $\%$ & $\begin{array}{l}4 \\
7.8\end{array}$ & $\begin{array}{c}21 \\
\% 41.2\end{array}$ & - & $\begin{array}{c}1 \\
\% \quad 2\end{array}$ & $\begin{array}{c}1 \\
\% \quad 2\end{array}$ & $\stackrel{2}{\% 3.9}$ & $\begin{array}{c}1 \\
\% \quad 2\end{array}$ & 51 \\
\hline MS B & $\begin{array}{c}9 \\
\% 24.3\end{array}$ & $\begin{array}{c}11 \\
\% 29.7\end{array}$ & $\begin{array}{c}5 \\
\% 13.5\end{array}$ & $\begin{array}{c}1 \\
\% \quad 2.7\end{array}$ & & - & - & - & 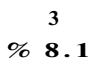 & - & - & - & $\begin{array}{c}8 \\
\% 21.6\end{array}$ & - & 37 \\
\hline Diğer & $\begin{array}{ll} & 2 \\
\% & 6.9\end{array}$ & $\begin{array}{c}3 \\
\% 10.3\end{array}$ & $\begin{array}{ll} & 2 \\
\% & 6.9\end{array}$ & $\begin{array}{c}6 \\
\% 20.7\end{array}$ & & $\begin{array}{l}1 \\
3.4\end{array}$ & $\%$ & $\begin{array}{l}2 \\
6.9\end{array}$ & $\begin{array}{r}9 \\
\% 31\end{array}$ & $\begin{array}{c}1 \\
\% 3.4\end{array}$ & - & $\begin{array}{c} \\
1 \\
\% 3.4\end{array}$ & $\begin{array}{ll} & 2 \\
\% & 6.9\end{array}$ & - & 29 \\
\hline Toplam & $\begin{array}{c}76 \\
\% 26.2\end{array}$ & $\begin{array}{c}79 \\
\% 27.2\end{array}$ & $\begin{array}{c}31 \\
\% 10.7\end{array}$ & $\begin{array}{c}23 \\
\% \quad 7.9\end{array}$ & $\%$ & $\begin{array}{l}4 \\
1.4\end{array}$ & $\%$ & $\begin{array}{l}7 \\
2.4\end{array}$ & $\begin{array}{c}43 \\
\% 14.8\end{array}$ & $\begin{array}{c} \\
\\
\% \quad 0.7\end{array}$ & $\begin{array}{c}1 \\
\% \\
0\end{array}$ & 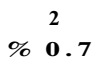 & $\begin{array}{c}20 \\
\% \quad 6.9\end{array}$ & $\begin{array}{c}2 \\
\% 0.7\end{array}$ & 290 \\
\hline
\end{tabular}

$\mathbf{X}^{2}=\mathbf{1 5 0 . 0 6}$

$\mathbf{P}<0.05$

(1: Hasta tabelası normal vizit"; 2: Hasta tabelası hekim imzası ile C.V." 3: Uyuşturucu reçete; 4: Uyuşturucu reçete ve hasta tabelası hekim imzası ile C.V."; 5: Diğer ) 
hasta tabelasına göre hekim tarafından düzenlenmiş ilâç listesi ile isteme izlemektedir. (Tablo XV). Yapılan $\mathrm{x}^{2}$ testi, eczaneden ilaç istenmesinde kullanılan yöntem bakımından, dört grubun da birbirinden farklı olduğunu ortaya koymuştur. SSYB hastanelerinde en çok kullanılan yöntem, hasta tabelasına göre hemşire tarafından hazırlanmış ilaç listesi ile ilaç istenmesidir (\% 40.3). Bu yöntem diğer hastanelerde \% 31 oranında kullanılmakta; buna karşılık MSB hastanelerinde yalnızca \% 2.7 oranında kullanılmakta, SSK hastanelerinde ise hiç kullanılmamaktadır. SSK hastanelerinin hemen tamamında (\% 93.9) kullanılan yöntem, doğrudan doğruya hasta tabelası ile ilaç istenmesidir. Bu yöntem MSB hastanelerinde de çok kullanılmakta (\% 81.1), buna karşılık SSYB hastanelerinde \% 34.7, diğer hastanelerde ise \% 44.8 oranında kullanılmaktadır.

\section{Eczaneden Servislere Günlük İlaç Dağıtımında Kullanılan Yöntem}

Yapılan $\mathrm{x}^{2}$ testine göre, eczaneden servislere günlük ilaç dağ 1 tımında kullanılan yöntem bakımından, SSYB dışındaki gruplar arasında fark yoktur. Hasta adına ilaç verilmesi yöntemi (hastanın bütün ilaçları her hasta adına ayrı ayrı verilir) SSK hastanelerinde \% 87.8, MSB hastanelerinde \% 86.5 ve diğer hastanelerde \% 72.4 gibi yüksek oranlarda kullanılırken, SSYB hastanelerinde \% 44.3 oranında kullanılmaktadır. Servis adına ilaç verilmesi yöntemi (bir serviste yatan hastaların aynı cinsten olan ilaçlarının hepsi biraraya konularak verilir) SSK hastanelerinde \% 6.1, MSB hastanelerinde \% 13.5 ve diğer hastanelerde \% 10.3 gibi düşük oranlarda kullanılırken, SSYB hastanelerinde \% 39.2 gibi diğer gruplara kıyasla yüksek oranda kullanılmaktadır. (Tablo XVI.).

\section{Eczane Kayitlarinı Tutan Personel}

Yapılan $\mathrm{x}^{2}$ testi, SSYB hastaneleri ile diğer hastaneler arasında fark olmadığını; buna karşılık SSK ve MSB hastanelerinin hem birbirinden, hem de diğerlerinden farklı olduğunu ortaya koymuştur. SSYB hastaneleri ve diğer hastanelerde, kayıtlar benzer oranda (\% 60.6 ve \% 65.5) başeczacı ve / veya eczacılar tarafından tutulmaktadır. Bu oran SSK hastanelerinde \% 45.1 , MSB hastanelerinde ise \% 29.7 dir. SSYB hastaneleri ve diğer hastanelerde, kayıtlar gene 
Tablo XV. Serviste Yatan Hastalar İçin Eczaneden ilaç

İstenmesinde Kullanılan Yöntem

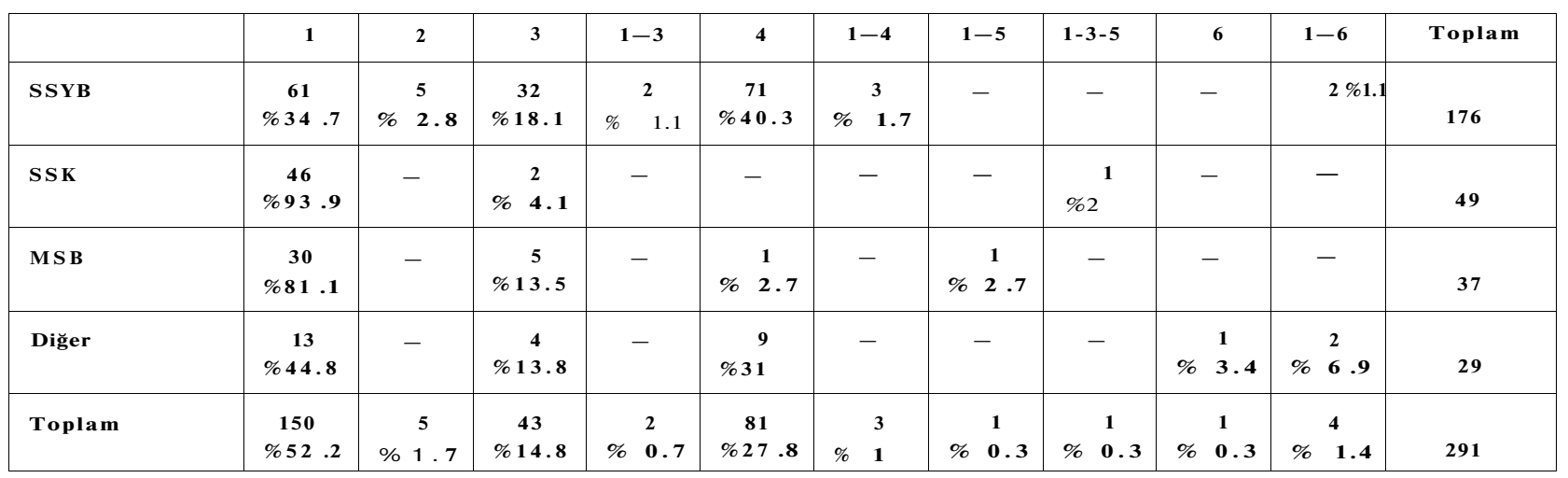

$\mathrm{X}^{2}=\mathbf{1 0 8 . 9 4}$

$P<0.05$

( 1 : Hasta tabelası; 2: Hasta tabelasının karbon kopyası; 3: Hekimin hazırladığı ilaç listesi; 4: Hemşirenin hazırladı̆̆ı ilaç listesi; 5 : Hemşire istasyonuna çıkan eczacı kalfasının hazırladığı ilaç listesi.) 
Tablo XVI. Eczaneden Servislere Günlük Ílaç Dağıtımında

Kullanilan Yöntem

\begin{tabular}{|l|c|c|c|c|}
\hline & Servis Adına & Hasta Adına & Karışık & Toplam \\
\hline SSYB & $69(\% 39.2)$ & $78(\% 44.3)$ & $29(\% 16.5)$ & 176 \\
\hline SSK & $3(\%(6.1)$ & $43(\% 87.8)$ & $3(\%(6.1)$ & 49 \\
\hline MSB & $5(\% 13.5)$ & $32(\% 86.5)$ & 37 \\
\hline Diğer & $3(\% 10.3)$ & $21(\% 72.4)$ & $5(\% 17.2)$ & 29 \\
\hline Toplam & $80(\% 27.5)$ & $174(\% 59.8)$ & $37(\% 12.7)$ & 291 \\
\hline
\end{tabular}

$\mathbf{X}^{2}=50.04 \quad P<0.05$

benzer oranda (\% 34.9 ve \% 34.5) başeczacı ve / veya eczacılar ve diğer personel tarafından tutulmaktadır. Bu oran SSK hastanelerinde \% 54.9, MSB hastanelerinde ise \% 51.4 tür. MSB hastanelerinde; ve diğer hastanelerde SSK hastanelerinde hiç görülmeyen, SSYB hastanelerinde ise çok düşük oranda (\% 4.6) görülen bir durum göze çarpmaktadır: kayıtlar \% 18.9 oranında yalnızca eczacı dışında personel tarafindan tutulmaktadır (Tablo XVII).

Tablo XVII. Eczane Kayitlarinı Tutan Personel

\begin{tabular}{|l|c|c|c|c|}
\hline & 1 & 2 & Toplam \\
\hline SSYB & $106(\% 60.6)$ & $61(\% 34.9)$ & $8(\% 4.6)$ & 175 \\
\hline SSK & $23(\% 45.1)$ & $28(\% 54.9)$ & 51 \\
\hline MSB & $11(\% 29.7)$ & $19(\% 51 \mathrm{k})$ & $7(\% 18.9)$ & 37 \\
\hline Diğer & $19(\% 65.5)$ & $10(\% 34.5)$ & - & 29 \\
\hline Toplam & $159(\% 54.5)$ & $118(\% 40.4)$ & $15(\% 5.1)$ & 292 \\
\hline
\end{tabular}

$\mathbf{X}^{2}=30.04 \quad P<0.05$

(1: Başeczacı ve / veya eczacılar; 2: Başeczacı ve / veya eczacılar ve diğer personel;

3: Diğer personel.)

\section{SONUÇ ve TARTIŞMA}

Yurdumuzda, geleneksel hastane eczacılığı hizmetlerinin gerektiğince yürütüldüğü söylenemez. Bunun iki nedeni vardır. Birinci neden, eczacılık eğitiminde hastane eczacılığına yeterince önem verilmemesidir. Tüm yataklı tedavi kurumlarında görevli eczacıların \% 
63.9'u kendisini bir veya birden çok konuda yetersiz bulmaktadır. (Tablo V). Hastane eczacılığı, ders olarak yalnızca Hacettepe Üniversitesinde - o da bir ders dönemi ve haftada bir saat- okutulmaktadır. Diğer bir eczacılık eğitim kurumundan yeni mezun olan bir eczacının herhangi bir hastane eczanesinde görev aldığını düşünelim. Eczacılık eğitim kurumlarında hastane eczanesi stajı zorunlu değildir. Diğer bir deyişle, yeni mezun olan bir eczacının hastane eczanesinde staj yapmış olması tamamen şansa kalmıştır. Nitekim tüm yataklı tedavi kurumlarında görevli eczacıların (MSB grubu dişında) yarıdan fazlası (\% 58.4) öğrencilikleri sırasında hastane stajı yapmamışlardır. (Tablo IV). Böyle bir eczacı, ne yapması gerektiğini orada görevli eczacı, bazen de teknisyen veya hemşireden usta-çırak ilişkisi sonucu öğrenecek ve bu bilgileri sonradan gelecek olan meslekdaşlarına aynı çarpık yöntemle aktaracaktır. Sonuçta, öğrenilenler, kişisel çaba ve deney sonucu elde edilen, bilimsel esasa dayanmayan bilgi] er olacaktır.

İkinci neden, hastane eczanelerinin çalışma düzeninin yurt çapında standardize edilmemiş olmasıdır. Yurdumuzdaki yataklı tedavi kurumları çeşitli kuruluşlara bağlıdır. Bu kuruluşlarca hazırlanan, hastane eczanesinin çalışma düzeninim belirleyen yazılı kurallar arasında farklar vardır. Hastaneye ilaç alınması, alınan ilaçların kontrolü, serviste yatan hastalar için eczaneden ilaç istenmesi, eczaneden servislere günlük ilaç verilmesi ve eczane kayıtlarının tutulması gibi geleneksel hastane eczacılı̆̆ının ana konularında yataklı tedavi kurumlan arasında görülen farklar, istatistiksel olarak incelendiğinde önemli bulunmuştur. (Tablo IX, X, XIV, XV, XVI, XVII)

Hastane eczacılığımızın sorunları ancak eczacılık eğitim kurumları arasında ve eğitim kurumları ile yataklı tedavi kurumlarının bağlı olduğu kuruluşlar ve konuyla ilgili diğer kuruluşlar arasında İşBÖLÜMÜ ve EŞG ÜDÜM sağlanmasıyla çözümlenebilir. Bu sayede, yeterli ve yurt gerçeklerine uygun teorik ve pratik eğitim programları hazırlanarak, bu programlar fakültelerde ve hastane eczanelerinde uygulamaya konabilir. Gene bu sayede hastane eczacisının görev ve sorumluluk çerçevesini ve hastane eczanesinin çalışma düzenini belirleyen yazılı kurallar arasındaki farklar giderilerek, tek tip, yeterli ve yurt gerçeklerine uygun kural zincirine gidilebilir. 
Eczacılık eğitim kurumlarında gerekli düzenlemeler yapılarak ve kurallar arası farklar giderilerek geleneksel hastane eczacılığımız rayına oturduktan sonra, halk sağlığı için çok daha yararlı olan klinik eczacılığa geçilebilir. İlgili tüm kuruluşların zaman yitirmeden konuya eğilmeleri, hastane eczacılarının halk sağlığına olan katkılarını arttıracak ve onları sağlık ekibindeki gerçek yerine oturtacaktır.

\section{ÖZET}

Hastanelerde klinik eczacılı̆̆ın temeli, geleneksel hastane eczacılığıdır. Geleneksel hastane eczacılığı tam anlamıla yerleştirilmeden, klinik eczacılığa geçilemez. Yurdumuzda, geleneksel hastane eczacılığının tam anlamıyla yürütüldüğü söylenemez. Bunun nedenleri, eczacılık eğitimindeki eksiklikler ve yataklı tedavi kurumlarındaki hastane eczanesinin çalışma düzenini belirleyen kuralların birbirinden farklı olmasıdır. İlgili tüm kuruluşlar arasında işbölümü ve eşgüdüm sağlanarak sorunlara çözüm getirilmelidir.

\section{S U M M A R Y}

In hospitals, the basis of clinical pharmacy is traditional hospital pharmacy. Unless the traditional hospital pharmacy is truly built up, it is impossible to establish the clinical pharmacy. It can not be told that the traditional hospital pharmacy in Turkey is thoroughly working. The causes are the unsufficiency of the pharmacy education and the differences between the regulations regarding the work flow of hospital pharmacies. By the cooperation and coordination between all the units connected with the topic, solution to these problems should be found. 